\title{
Structural Analysis of Industrial Foam Crusher Machine By Using Finite Element Method
}

\author{
Emir Esim $^{1 *}$, Emre Benzer ${ }^{2}$ \\ ${ }^{1}$ Erciyes Üniversitesi, Mühendislik Fakültesi, Mekatronik Bölümü,Kayseri, Türkiye (ORCID: 0000-0003-0801-9155) \\ ${ }^{2}$ Kilim Furniture, R\&D Center, Kayseri, Türkiye (ORCID: 0000-0002-8587-4377)
}

(International Symposium on Multidisciplinary Studies and Innovative Technologies (ISMSIT) 2021 - 21-23 October 2021)

(DOI: 10.31590/ejosat.1012035)

ATIF/REFERENCE: Esim, E. \& Benzer, E. (2021). Structural Analysis of Industrial Foam Crusher Machine By Using Finite Element Method. European Journal of Science and Technology, (29), 343-350.

\begin{abstract}
Especially in the foams used in sectors such as furniture, mattress, automotive, textile, deformation occurs depending on time and load. This situation leads to a decrease in customer satisfaction. In order to solve this problem, a machine has been developed to eliminate internal irregularities with the sponge block crushing method in order to eliminate the formations such as sticky or irregularity of the voids/channels in the inner structure of the sponge blocks after curing and to minimize the deformation that will occur in the short term after production. In this study, structural analysis was carried out for the geometric optimization of the parts that make up the crushing machine designed. For this purpose, linear static analysis of foam crusher parts is realized and maximum Von Misses stress, deformation, the factor of safety results and necessary optimization locations are determined via ANSYS Workbench software. The obtained results are presented in graphics.
\end{abstract}

Keywords: Foam crusher, Finite element analysis, Structural analysis, Stress analysis

\section{Endüstriyel Sünger Ezme Makinesinin Sonlu Elemanlar Yöntemi İle Yapısal Analizi}

Öz

Özellikle mobilya, yatak, otomotiv, tekstil gibi sektörlerde kullanılan süngerlerde zamana ve yüke bağlı olarak deformasyon meydana gelmektedir. Bu durum müşteri memnuniyetinin azalmasına neden olmaktadır. Bu sorunu çözmek için sünger blokların iç yapısındaki boşlukların/kanalların yapışkanlık veya düzensizlik gibi oluşumların giderilmesi; kürleme ve üretim sonrası kısa vadede oluşacak deformasyonu en aza indirmek amacıyla sünger blok ezme yöntemi kullanılmaktadır. Bu çalışma ile ile sünger iç düzensizlikleri ortadan kaldıracak bir ezme makinesi geliştirilmiştir. Bu çalışmada tasarlanan kırma makinesini oluşturan parçaların geometrik optimizasyonu için yapısal analiz yapılmıştır. Bu amaçla sünger ezme makinası parçalarının lineer statik analizi yapılarak ANSYS Workbench yazılımı ile maksimum Von Misses gerilmesi, deformasyonu, emniyet katsayısı sonuçları ve gerekli optimizasyon bölgeleri belirlenmiştir. Elde edilen sonuçlar grafiklerle sunulmuştur.

Anahtar Kelimeler: Sünger ezme, Sonlu elemanlar metodu, Yapısal analiz, Gerilme analizi

\footnotetext{
${ }^{*}$ Corresponding Author: Erciyes Üniversitesi, Mühendislik Fakültesi, Mekatronik Bölümü, Kayseri, Türkiye, ORCID: 0000-0003-0801-9155, emiresim@erciyes.edu.tr
} 


\section{Introduction}

In the sponge production sector, generally, after the block sponge is cured on the shelf, sizing is performed, especially in the furniture sector, mattresses, quilting, woven textile quilting, armchairs, sofas, etc. production is done.(De Mello, Pezzin, \& Amico, 2009) In the production of sponges, different types of sponges are cut by using advanced cutting techniques such as roll, rotary cutting, horizontal cutting, profile, and CNC. Thus, different sizes and types of sponges can be produced according to their needs.

Mechanical properties are often believed to be important for PUR foams used in the furniture industry $(\mathrm{Li}, \mathrm{Yang}, \mathrm{Li}$, Jiang, \& Liang, 2018)Over time, the fabric on an upholstered sofa loosens. In fact, it is not the fabric that deforms. It is a foam that deforms over time. Therefore, it is always very important to check the mechanical performance of foam under a certain load in an upholstered frame.(Demirel \& Ergun Tuna, 2019) Gök et al. has investigated the hardness values of polyurethane foam used in furniture upholstery(Gok et al., 2012) Marsivana et al. have investigated the failure of polyurethane foams under different loading conditions.(Marsavina, Sadowski, Constantinescu, \& Negru, 2008)Demirel and Tuna measured the changes in indentation force deflection (IFD) hardness and thickness values after constant fatigue loading on polyurethane (PUR) foams of six different densities and two different categories.(Samet Demirel 2019)

Ulrich (1983) stated that flexible polyurethane foams produced from polycondensation of polyols with isocyanate are formed as open-celled with low density and limited mechanical strength, with high gas permeability. (H.Ulrich, 1983).Quintero et al. found that the tear resistance decreased with the increase in cell diameter of the flexible foams they produced.(Quintero et al., 2009) Besides, after the sponges are cured since the cells that are not fully formed in them are not broken, it causes the complaints of collapse in the bed and collapse in the sofa in the future. In this study, it is aimed to reduce the height loss, which is expressed as sponge collapse, with the crushing machine designed. In addition, the unbroken cells in the sponge are broken and the structure is normalized. In general, the expectations from a crushing process can be listed as follows;

The designed machine produces a wide variety of Foam processing and auxiliary equipment, among them is the foam crusher. An essential part of any foam production, the crusher is used to open the foam cells by compressing the foam down to $10 \%$ of its volume. Foam crushing is essential in hi-resiliency and memory foam production. Another important use is to reclaim dead foam (closed-cell foam) into open-cell foam the crushing process involves running the sheet or block thru the rollers back and forth until the desired open-cell percentage is attained. Blocks are usually crushed right after curing to be further crushed before cutting.

By using finite element-based simulations, unexpected design errors that may occur during the testing of components of mechanical designs are naturally reduced. In addition, studies can be carried out for the performance and reliability analysis of the systems with the solid model of the systems produced by computer-aided design (CAD). Structural analyzes with such programs are widely preferred in determining the strength of mechanical systems. In this way, undesirable situations in terms of both the material to be used and the mechanical strength are determined before the production of the mechanical components.

Today, many finite element methods are used, from various engineering fields such as construction, electricity, machinery, aircraft, hydrodynamics, atom to the field of medicine. Examples of these studies can be given as examples for machine design and analysis(Chen, Das, \& Battley, 2017; Mustafa Tinkır \& Sezgen, 2017) for vibration analysis (Demirtaş \& Bayraktar, 2019; Y1ldırım 2019)and dental applications(Aslan, Esim, Ustun, \& Donmez Ozkan, 2021). Many machine designs have been made for sponge production in the sponge sector, and the main ones are sponge cutting machines. (Liu, 2021). At the same time, there is a need for a machine design for crushing sponges for the reasons mentioned above. Studies on such structures designed for crushing are insufficient in the literature. In addition, in the design of the sponge crushing machine, structural analyzes with the finite element method were not encountered to ensure that the machine is safe and secure.

In this study, solid modeling and structural analysis of a system to be used for sponge crushing operations are presented. To transform the analysis into real system behavior, structural analysis was carried out with the forces determined according to the characteristics of the sponge crushing system. From the analysis results, it has been seen that the material and structure used in the crushing system provide simple, reliable, and costeffective production requirements.

The parts of this study are as follows; In the following section, the mechanical design of the crushing machine that forms the system is given. Then, structural analyzes and their results are given in Section 3,4 respectively. Finally, the conclusion part, which expresses the contributions of the analysis results to the design studies, is given.

\section{Material and Method}

In general, sponge blocks are produced in the structure given in figure 1 , with a length of $20 \mathrm{~m}$, a height of $1200 \mathrm{~mm}$, and a width of $2000 \mathrm{~mm}$. These blocks are then produced and used by cutting them into desired lengths and sizes. These blocks, which are produced to increase the sponge quality before the cutting process, to eliminate unwanted errors in the use, and to open the cells that are not fully opened, are subjected to the crushing process on the line as seen in Figure 2.

As seen in the figure, the crushing process is carried out by the angled rotation of the rotary cylinder, which has double jaws on the crusher machine and can crush gradually on these jaws. In addition, there are 2 pistons on the crushing machine, one of the pistons is in the upper jaw the other one is in the lower jaw, to adjust the crushing angle.

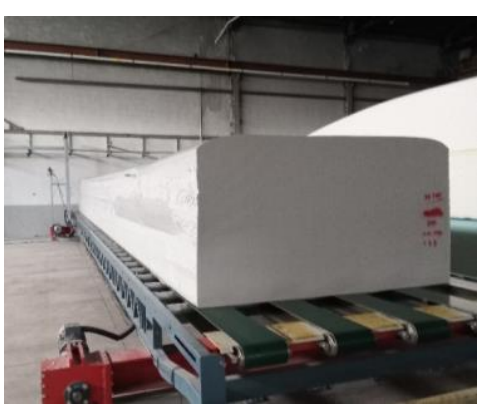

Figure 1. Sponge block view 


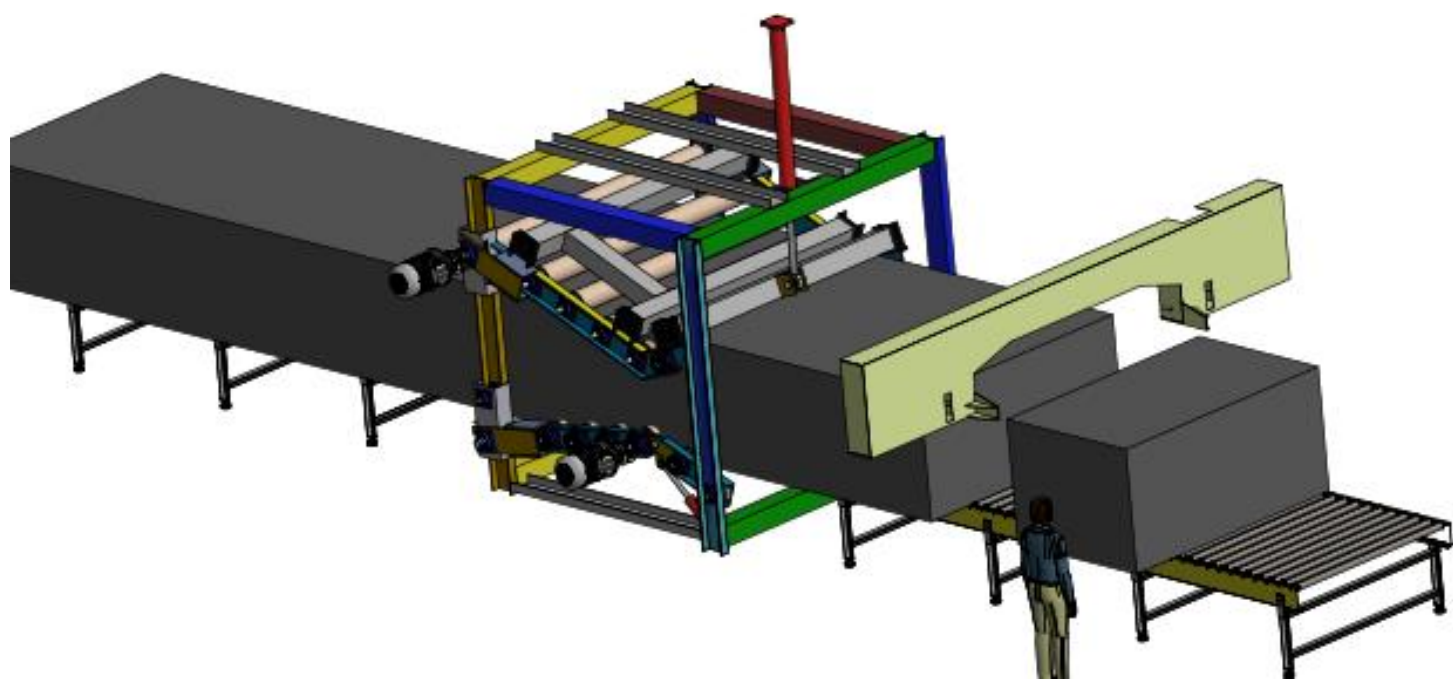

Figure 2. Sponge crushing process view

In addition, the rotation of the rotating wheels is provided by chain gears. Two $7.5 \mathrm{~kW}$ two motors and reducer groups were used for the movement of the upper and lower cylinders. As can be seen from the figure, the crushing machine has a very complex design because it consists of many elements.

As the complexity of the system increases, it becomes difficult to produce a theoretical solution. In such cases, approximate solution methods are used. The most common of these methods is the Finite Element Method. In this method, the system, which is referred to as the "mesh" operation in the literature, is divided into uniform geometric small elements and the solution is realized in this finite element network with various assumptions. The larger the size of the finite element mesh, the more difficult the solution, but more realistic results can be obtained. For this reason, one of these programs, SolidWorks, was used in the creation of the solid model of the crusher machine in this study and performing its static analysis with ANSYS Workbench.

The solid model of the designed crushing machine is given in Figure 3. CAD model of crusher is imported into ANSYS with Parasolid file format.

After the design of a mechanical system, calculating its response to external loads in pre-production operating conditions is extremely important for the safety and security of the system. While theoretical solutions are possible for simple structures, theoretical solutions become more difficult as the complexity of the system increases. In such structures, methods that produce approximate solutions are preferred. The Finite Element Method is one of the most used methods. In this method, the structure to be analyzed is divided into regular geometric small elements defined as "mesh" operations. and by making some assumptions for the solution, the solution is realized in this finite element network. The smaller the finite element size, the more difficult the solution, but results closer to the theoretical solution can be obtained. Many analysis programs use the Finite Element Theory. For example Ansys, Solid Works, Catia, etc. Thanks to these Programs, many systems can be analyzed according to operating conditions without having to know much about the details of finite element theory. For this reason, the Solidworks program was used in the creation of the solid model of the crushing machine designed in this study, and the ANSYS program was used in the static analysis.

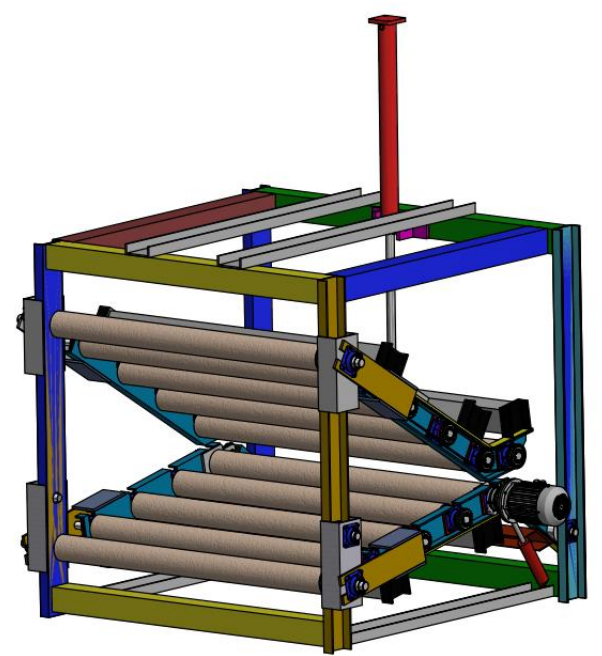

Figure 3. Foam crusher machine CAD Model

\section{Static Structural Analysis}

The structural analysis of foam crusher is realized, weak and more strength areas of crusher body parts are determined using finite element method. Before the analysis, some required shape optimizations of the CAD model are done. The connection holes, chain, gears, and hydraulic adapter of the crusher are removed from the CAD model. Also, The analysis model has been simplified by removing some structures that will not affect the analysis from the model. Some radius disturbed mesh geometry is removed.

The finite element method is based on the division of the components to be analyzed into finite small parts. The smaller the size of these parts, the more precise the solution is obtained. However, the increase in the number of elements significantly increases the analysis time. This may cause the computer to be used in the analysis to be insufficient in terms of both processor and memory. For this reason, to provide precision in the process of dividing apples, an average of $10 \mathrm{~mm}$ element sizes were determined. This model consists of 1416214 element numbers and 2510241 node numbers. The meshed model of the crusher is 
given in Figure 4. In this study, the mesh model is achieved by using quadrilateral and triangular elements in ANSYS Workbench software

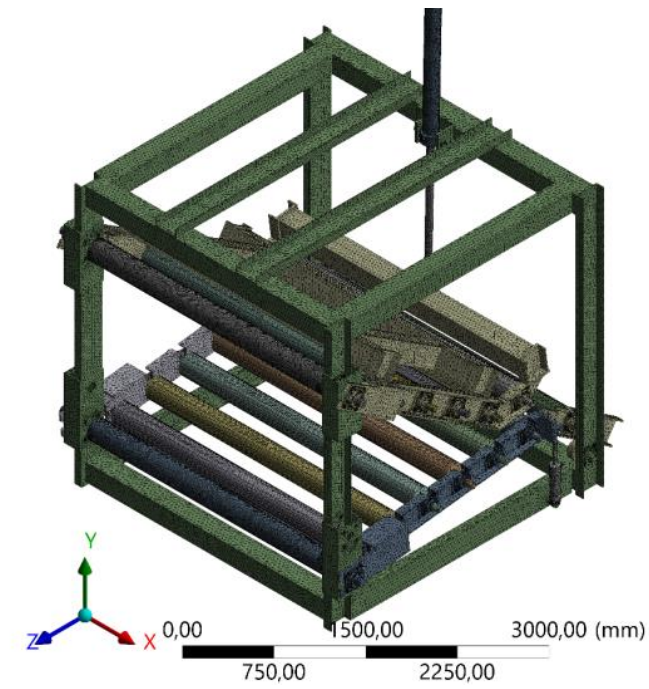

Figure 4. View of the mesh structure

After the meshing, material properties are defined for the Finite Element Model. In all calculations, the materials used in the crusher are assumed to be homogeneous and isotropic. Material properties are given in Table 1.

Table 1. Mechanical properties of the materials

\begin{tabular}{|c|c|c|c|c|c|c|}
\hline 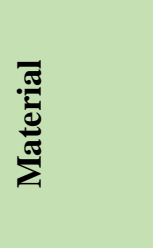 & 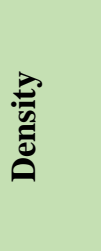 & 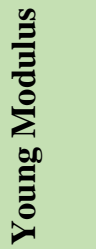 & 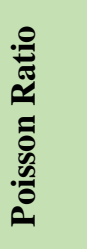 & 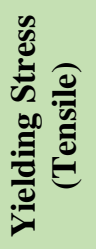 & 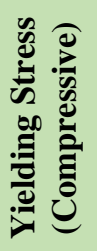 & 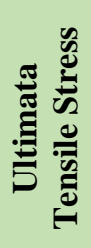 \\
\hline $\begin{array}{c}\text { Structural } \\
\text { Steel }\end{array}$ & $\begin{array}{c}7850 \\
\mathrm{~kg} / \mathrm{m}^{3}\end{array}$ & $\begin{array}{l}210 \\
\mathrm{GPa}\end{array}$ & 0.3 & $\begin{array}{l}250 \\
\mathrm{MPa}\end{array}$ & $\begin{array}{l}250 \\
\mathrm{MPa}\end{array}$ & $\begin{array}{l}460 \\
\mathrm{MPa}\end{array}$ \\
\hline
\end{tabular}

After the crane system is divided into elements contact processes have been defined for the structures in contact with each other on the crusher system. The appearance of the boundary conditions of the system is given in Figure 5 . Fixed support is defined as the bottom of the machine.

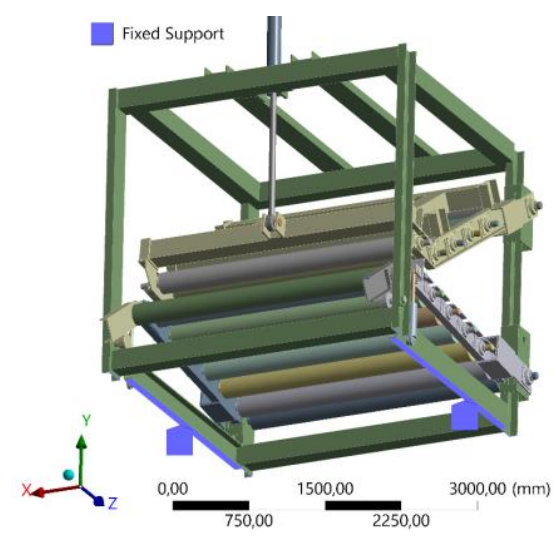

Figure 5. Boundary condition of the system

\subsection{Calculation of Forces}

Sponge blocks are produced in different densities according to the place to be used. This value, which is expressed as the property of the sponge, is produced in different densities up to 32 $\mathrm{kg} / \mathrm{m} 3.32$ density material is very hard and there is no need for crushing. However, according to customer demands, the hardest material that will need to be crushed is 28 density. To determine the force required to be applied in the rollers of the crushing machine to crush the sponge with this feature, compression tests were carried out according to different crushing rates. In these experiments, the sponge pressing device in figure 6 , which is located in the company and used to determine the sponge properties, was used. The force results obtained according to different crushing ratios as a result of these tests are given in Table 2. Here, a $200 \mathrm{~mm} \times 200 \mathrm{mmx} 120 \mathrm{~mm}$ sponge was used to determine the required force for a block-shaped $1200 \mathrm{~mm}-2000 \mathrm{~mm}$ sponge. By proportioning the results obtained, the required force values were obtained for each crushing step according to the crushing ratio. 


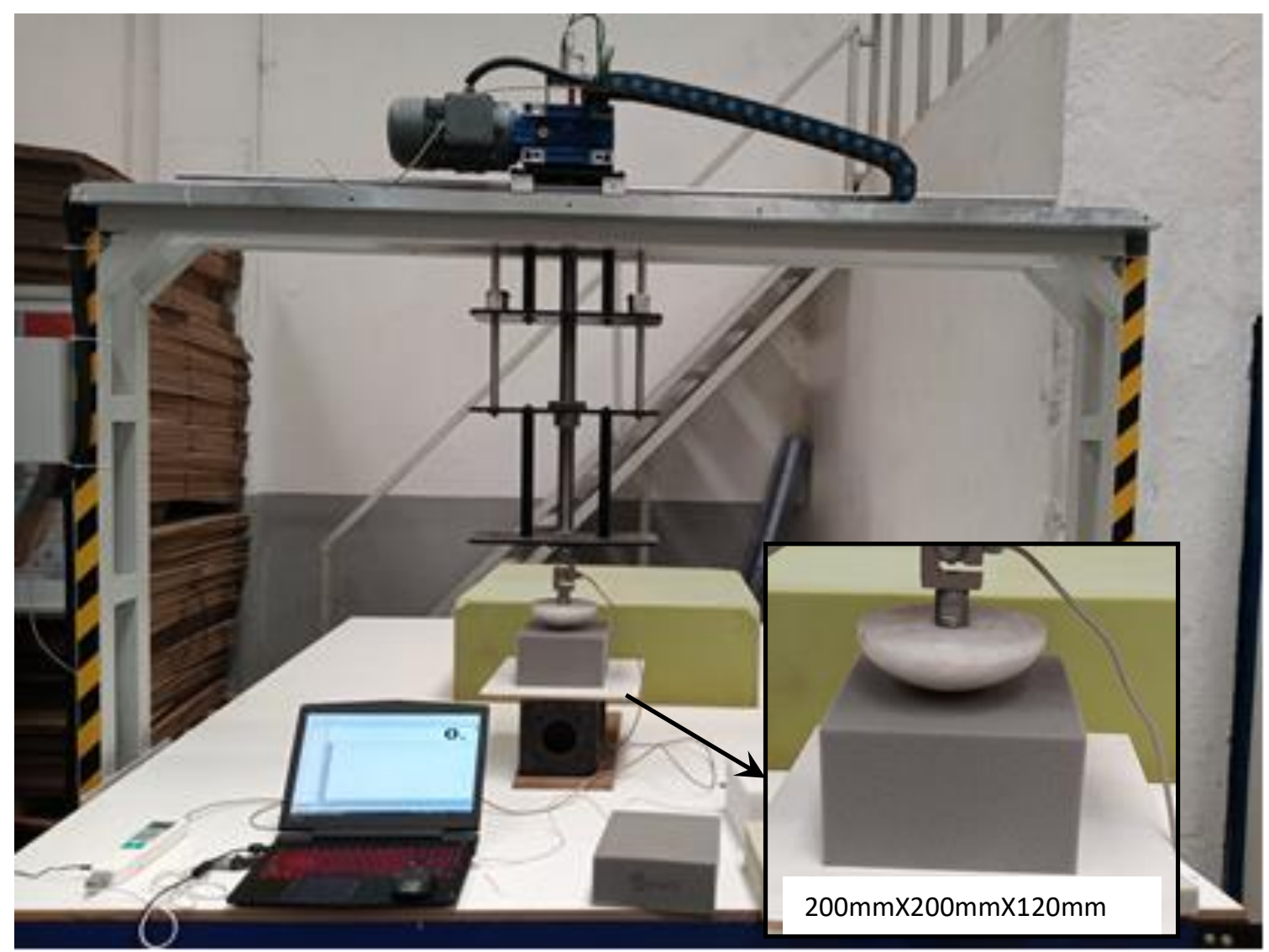

Figure 6. View sponge compression device and sponge sample

Table2. Result of Compression test

\begin{tabular}{|c|c|c|c|c|c|c|c|c|c|c|c|}
\hline \multicolumn{10}{|c|}{28 Density Foam } \\
\hline Crush Rate & 1,09 & 1,20 & 1,33 & 1,50 & 1,71 & 2,00 & 2,40 & 3,00 & 4,00 & 6,00 & 12,00 \\
\hline Force (N) & 5,00 & 15,00 & 28,00 & 42,00 & 54,00 & 67,00 & 79,00 & 89,00 & 102,00 & 132,00 & 200,00 \\
\hline
\end{tabular}

Considering the maximum crushing position for the designed crushing machine, the crushing process is carried out in 5 stages. The force values calculated for these 5 stages are given in Table 3.

Considering the maximum crushing position for the designed crushing machine, the crushing ratios between the upper and lower jaws were determined by the SolidWorks program. Under these conditions, the crushing process is carried out in 5 stages. The force values calculated for these 5 stages are given in Table 3. These determined forces were applied to the lower and upper roller in opposite directions at each stage. Loading conditions were applied on the roller and showed in Figure 7.

Table 3. The calculated forces according to the crushing stages

\begin{tabular}{|l|l|l|}
\hline Crushing Stages & Crush Rate & Forces(N) \\
\hline 1.Stage & 1,09 & 500 \\
\hline 2.Stage & 1,50 & 4200 \\
\hline 3.Stage & 2,34 & 7720 \\
\hline 4.Stage & 5,36 & 12240 \\
\hline 5.Stage & 8,57 & 16110 \\
\hline
\end{tabular}

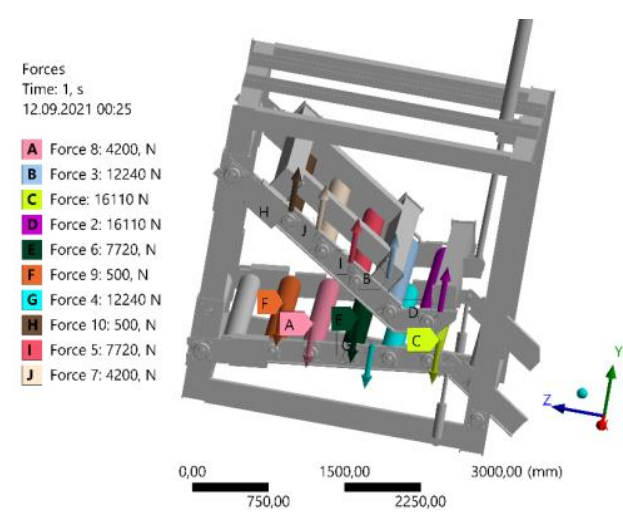

Figure 7. The Appearance of loads applied in crushing machine

\section{Result}

Static analysis is started by applying the forces obtained to the mechanical system whose meshing process is completed and sent to the relevant regions. After the analysis process, many mechanical properties related to the system are obtained both numerically and visually. 
In order to comment on the model, firstly, the stress results were obtained. Critical regions and safety coefficients were determined using Von Misses stress results. The results of the whole crusher system are given in Figure 9.

Type: Equivalent (von-
Unit: MPa
Time: 1
12.09.2021 00:31



$\mathbf{1 4 0 , 4 4}$ Max
124,83
109,23
93,624
78,02
62,416
46,812
31,208
15,604
$\mathbf{7 , 6 4 9 9} \mathbf{e}-\mathbf{1 0}$ Min

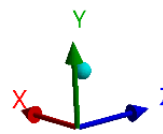

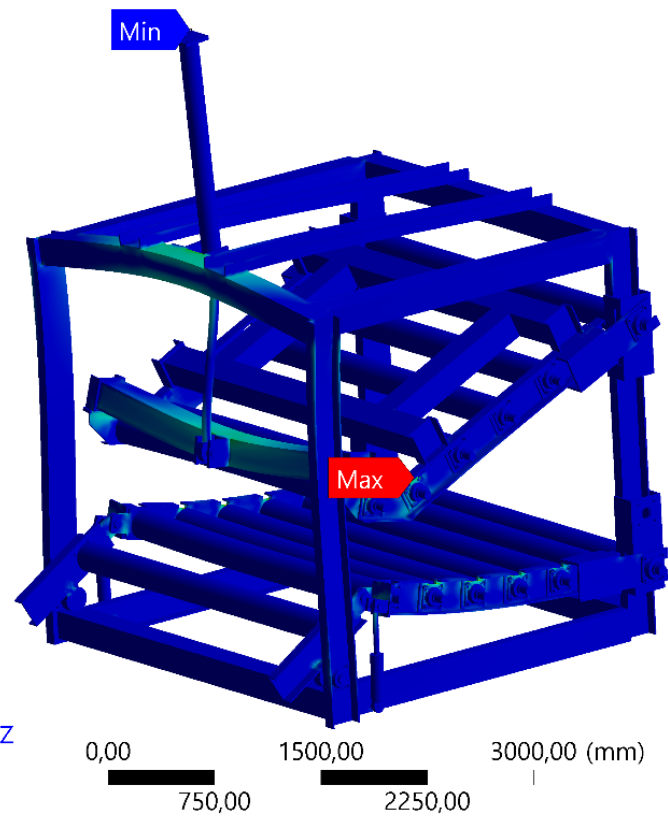

Figure 9. Von Mises stress distribution of the whole crusher

According to the given loading and boundary conditions, the maximum stress value on the system is $140.44 \mathrm{MPa}$, and it is seen that the crushing machine takes place in the upper jaw roller bear.
Since the crushing machine consists of many structures, the results of the machine components were also evaluated separately. The mainframe, lower and upper jaw stress values of the crushing machine are given in Figure 10.

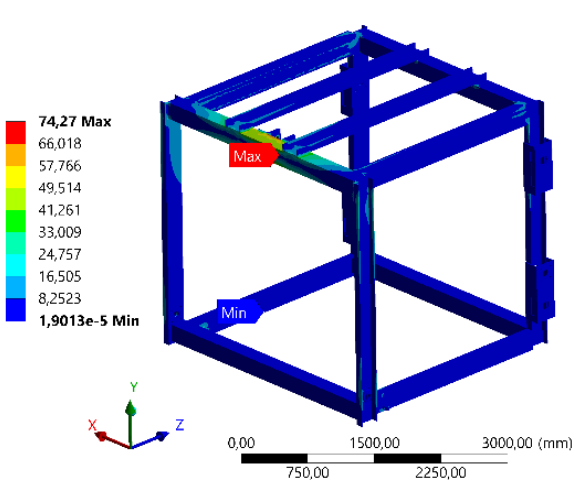

a) Main Frame

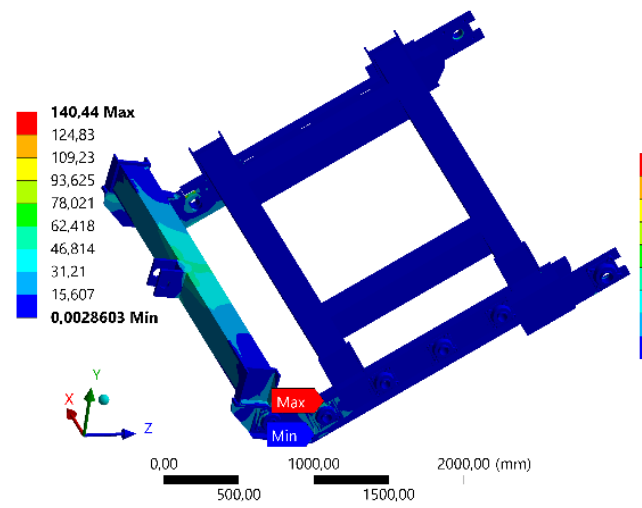

b) Upper Jaw

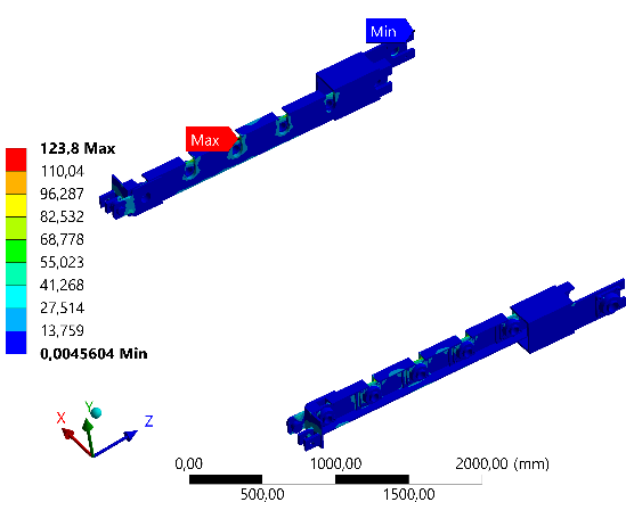

c) Lower Jaw

Figure 10. Von Mises stress distribution of crusher components a) Main Frame b)Upper Jaw c) Lover Jaw

As can be seen from the figure, there is a tension of 74.27 $\mathrm{MPa}$ in the main chassis, $123,8 \mathrm{MPa}$ in the lower jaw, and a maximum of $140,44 \mathrm{MPa}$ in the upper jaw.

The maximum stress ( $\sigma$ equivalent $==\sigma$ Max) that occurs in the part as a result of loading should always be a certain amount less than the yield strength $(\sigma y i e l d==\sigma f)$ of the material. This ratio is determined by a coefficient defined below as the safe working coefficient (SF, Safety factor)(Beer; E. Russell Johnston, Dewolf;, \& Mazurek, 2012).

$$
S F=\frac{\text { The yield strength of the material }}{\text { The equivalent maximum stress }}
$$

According to the stress values obtained above for the crushing machine, the chassis, lower and upper jaw safety coefficient changes are given in Figure 11. 


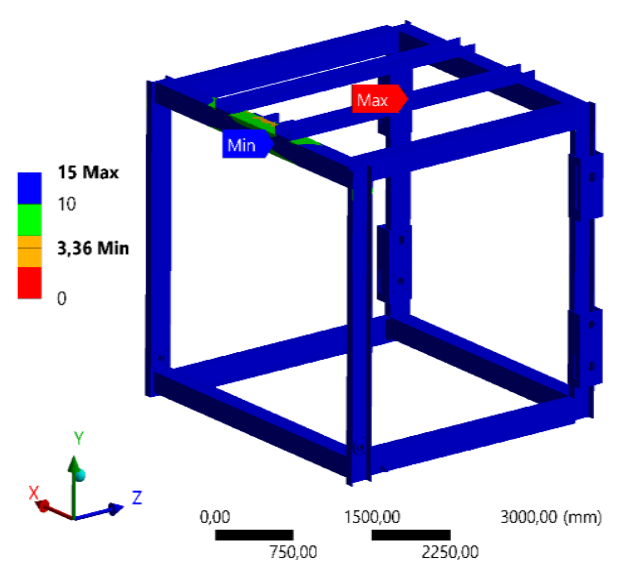

a) Main Frame

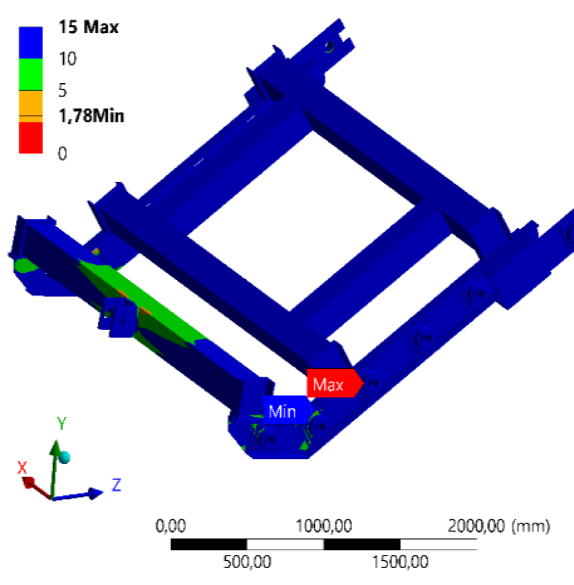

b) Upper Jaw

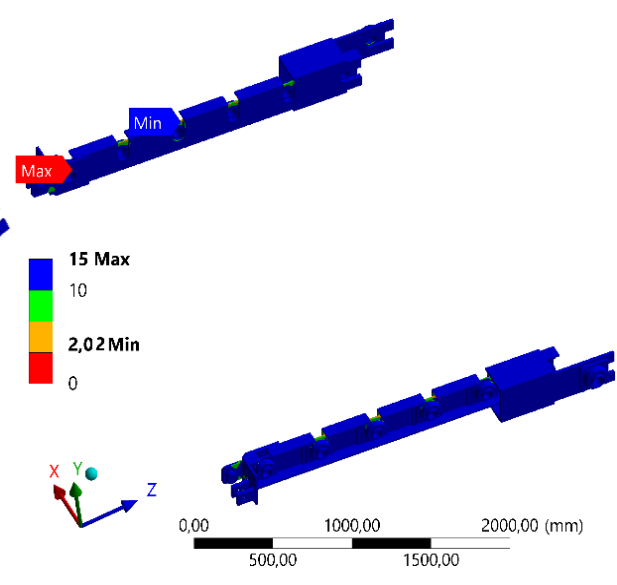

c) Lower Jaw

Figure 11. Safety factor values of crusher components a) Main Frame b)Upper Jaw c) Lover Jaw

When the safety coefficient results are examined, it is seen that the factor of safety is 1.78 for the upper jaw, 2.02 for the lower jaw, and 3.36 for the main chassis. In addition, the safety coefficients occurring in the left, right and upper hydraulic pistons were obtained as 3.93,3.18, and 3.10, respectively. According to these results, it is understood that the crushing machine and its components are safe and secure in order to crush the highest set sponge. In addition, since the force values to be applied in the crushing of sponges with low hardness will be less, it is understood that both the tensile and safety coefficients will be better at the expected values. Although the upper jaw roller bearing is sufficient according to both the stress and safety coefficient results, the design can be strengthened by enlarging the preferred bearings for crushing harder sponges.

\section{Conclusion}

In this paper, an industrial foam crusher machine is designed and structural analysis of crusher body parts is realized for geometric optimization. For this aim, linear static analysis is performed and maximum Von Misses stress locations, safety coefficients, maximum displacement results, and required optimization locations are determined via ANSYS Workbench finite element software.

The results obtained provide useful information for the companies producing sponges in terms of machine design that can crush. In addition, this study is useful and realistic in terms of reducing the materials to be used for the production of sponge crusher machines. With advanced design optimization techniques, it is possible to produce mechanical parts in more suitable scales. In addition, with topological optimization, the results can be improved according to fatigue analysis in future studies.

\section{Acknowledge}

We would like to thank Kilim Furniture Company for their contribution to our work.

\section{References}

Aslan, T., Esim, E., Ustun, Y., \& Donmez Ozkan, H. (2021). Evaluation of Stress Distributions in Mandibular Molar Teeth with Different Iatrogenic Root Perforations Repaired with Biodentine or Mineral Trioxide Aggregate: A Finite Element Analysis Study. $J$ Endod, 47(4), 631-640. doi:10.1016/j.joen.2020.11.018

Beer;, F., E. Russell Johnston, J., Dewolf;, J. T., \& Mazurek, D. F. (2012). Mechanics of Materials. New York: McGraw-Hill Companies.

Chen, Y., Das, R., \& Battley, M. (2017). Finite element analysis of the compressive and shear responses of structural foams using computed tomography. Composite Structures, 159, 784-799. doi:10.1016/j.compstruct.2016.09.091

De Mello, D., Pezzin, S. H., \& Amico, S. C. (2009). The effect of post-consumer PET particles on the performance of flexible polyurethane foams. Polymer Testing, 28(7), 702-708. doi:10.1016/j.polymertesting.2009.05.014

Demirel, S., \& Ergun Tuna, B. (2019). Evaluation of the cyclic fatigue performance of polyurethane foam in different density and category. Polymer Testing, 76, 146-153. doi:10.1016/j.polymertesting.2019.03.019

Demirtaş, A., \& Bayraktar, M. (2019). Free Vibration Analysis of an Aircraft Wing by Considering as a Cantilever Beam. Selcuk University Journal of Engineering ,Science and Technology, 7(1), 12-21. doi:10.15317/Scitech.2019.178

Gok, A., Yapıc1, F., Gulsoy, S. K., Kurt, S., Altun, S., Kilinc, I., \& Korkmaz, M. (2012). Determination of Static Fatigue Performance of Upholstery Foams. Kastamonu Univ., Journal of Forestry Faculty, 12, 285-290.

H.Ulrich. (1983). Urethane Polymers. Kirk- Othmer Encyclopedia of Chemical Technology. New York.: J. Wiley.

Li, A., Yang, D. D., Li, H. N., Jiang, C. L., \& Liang, J. Z. (2018). Flame-retardant and mechanical properties of rigid polyurethane foam/MRP/mg(OH 2/GF/HGB composites. Journal of Applied Polymer Science, 135(31), 46551. doi:10.1002/app.46551

Liu, W. (2021, 28-30 May 2021). Research on Technical Transformation and Innovative Design of Polyurethane Sponge Cutting Machine. Paper presented at the 2021 IEEE 
International Conference on Artificial Intelligence and Industrial Design (AIID).

Marsavina, L., Sadowski, T., Constantinescu, D. M., \& Negru, R. (2008). Failure of Polyurethane Foams under Different Loading Conditions. Key Engineering Materials, 385-387, 205-208. doi:10.4028/www.scientific.net/KEM.385-387.205

Mustafa Tınkır, \& Sezgen, H. Ç. (2017). Linear static analysis of hydraulic cylinder via finite element method. Omer Halisdemir University Journal of Engineering Sciences, Volume 6, Number 1, (2017), 203-212, 6(1), 203-212.

Quintero, M. W., Escobar, J. A., Rey, A., Sarmiento, A., Rambo, C. R., Oliveira, A. P. N. d., \& Hotza, D. (2009). Flexible polyurethane foams as templates for cellular glass-ceramics. Journal of Materials Processing Technology, 209(12-13), 5313-5318. doi:10.1016/j.jmatprotec.2009.03.021

Samet Demirel , B. E. T. (2019). Constant-Fatigue Performance of Different Polyurethane Foams for Sitting Purposes. Kastamonu Univ., Journal of Forestry Faculty, 19(2), 225234.

Yıldırım , Ş., Esim E.,. (2019). Modal Analysis of Double Beam Overhead Type Crane Systems by Finite Element Method. Konya Journal of Engineering Sciences, 7, 975-988. doi:10.36306/konjes.627067 